\title{
ON THE BOOK OF DEVOTIONS,
}

DEPOSITED BY CaRDINAL HOWARD IN THE LIBRART OF THE DOMINICAN CONYENT AT BORNHEIM IN 1659.

BY THE REV. JOSEPH HUNTER, F.S.A.

I AM permitted by Lady Stourton to whom it now belongs, to lay before the Institute a manuscript which will, I doubt not, be found, both on account of its beauty as a work of art, and of some circumstances of historical interest with which it is surrounded, to be eminently deserving their attention.

It is a book of Catholic devotions, one of the class called Missals in ordinary parlance; but like many other manuscripts usually so denominated, not a Missal in any proper sense of the word, but one of the class more properly called Horce, being a miscellany of prayers, collects, psalms, antiphons and pious ejaculations, adapted to the private use of a person of a devotional turn of mind; and we may add, for some person living in the world and not wholly given up to the religious life. It is adorned with various miniatures, representing, for the most part, early saints in the Christian Calendar with principal events in their lives, or peculiar events in the history of the Saviour. The text which follows the drawings, has usually reference, more or less direct, to the person or events which are there represented.

In form it is five inches by three and three quarters, and two inches in thickness. It is of the finest vellum, and is bound in crimson velvet, with silver corners slightly enchased. The number of leaves is 284 , and there are 34 large miniatures. The clasps have been removed. Some- thing appears to be wanting which preceded the shield of the arms of Hastings and the calendar at the beginning; and a very accurate observer who prepared an analysis of its contents, Mr. C. Weld, has remarked a slight dislocation or perhaps the loss of a leaf near the middle of the volume.

Besides the miniatures, there are ornamental borders to

VOL. XII. 
every page, consisting of flowers, animals, and arabesques, well selected, varied, and drawn, while the larger works are remarkable for the taste with which they are designed, and the delicacy with which they are executed. Attention may be called to the architecture and back-grounds of many of them, to the observance of the rules of perspective, to the air which is given to the figures, and to the expression in the countenances. Altogether, there are few works existing of this class in England which in these respects can pretend to more than a comparison with this manuscript, and scarcely any that surpass it in beauty.

It is a work of French or Flemish art ; and the costume guides us with tolerable certainty, to the latter half of the fifteenth century, 1470 to 1480 , as the period of the execution. Concurring to the same conclusion, is the language of a note in the English tongue near the beginning-" The sume of these Indulgences been xxvi. thousand yeres and xxxvi. daies| This writen in the chapel of Jherusalem, and this is registred in Rome." This will at least prove that it cannot have been written much later than the date which is here assigned to it.

The introduction of these few words of English while all the rest is in Latin, seems to show that it was prepared originally for the use of some person of the English nation. But this admits of still stronger proof from the selection which is made of the names of saints whose days are here particularly indicated in the calendar. There is an evident leaning to the introduction of the English saints. Thus we have St. Chad, St. Cuthbert, St. Richard, Elphege, Dunstan, Aldhelm, Swithen, Wolfran, St. Alban, and some others; persons whom an Englishman may be supposed to wish to have placed in his private calendar, but not claiming particular interest with a person of any other nation.

Assuming then, that we have sufficient reason to believe that it was a work of foreign art, French or Flemish, executed by a person eminent in this branch of art, about A.D. 1475 , and prepared for the use of an Englishman, it may be added, that so costly a work would hardly have been prepared but at the expense of some person of wealth and consideration; and the next question is, are there any means of determining for whom the book was originally prepared.

It must be acknowledged, that here we have no external 
evidence whatever : but the book seems itself to carry with it an indication which can scarcely mislead, of the person for whom it was executed, and to whom it originally belonged.

On the first leaf we have an heraldic drawing of singular beauty, and, doubtless, by the same hand that prepared the miniatures in the volume. It presents the arms of Hastings, the black maunch, surrounded by the Garter. Now this must have been the insignia of some member of the family of Hastings who had been admitted into the Order. Of these there was only one who lived within the period to which the book can possibly be assigned, namely, William, Lord Hastings, who was made a Knight of the Garter in 1461, and who was put to death by the Protector, Richard, Duke of Gloucester, in 1483. Two Hastings', in later generations of the family, viz.: Francis, Earl of Huntingdon, elected into the Order in 1549, and Sir Edward Hastings, Lord Hastings of Loughborough, in 1555, lived too late to be the owner of the shield here so beautifully delineated.

We seem, therefore, driven to the conclusion that the book was originally prepared for William, Lord Hastings, the Lord Chamberlain in the reign of King Edward IV. The religious character of Lord Hastings is manifested in the ecclesiastical foundations made by him, and his care in providing for the solemnities of his funeral and obits; while his long residence at Calais affords a presumption that he may have been brought into connection with some eminent French or Flemish artist, by whom the work was executed.

It did not, however, remain in the family of Hastings; and when we next get any authentic information respecting it, we find it in possession of the family of the Earl of Arundel, first, the Fitz-Alans (so called) or Arundels, and next the Howards, who enjoyed that eminent dignity by descent from the Arundels. It will be more convenient, and the facts will be presented in a more intelligible manner, if we trace the history of the book for the last two centuries backwards, beginning with the present possessor.

It was acquired by Lady Stourton, in 1835, by purchase from the English Dominicans in their convent at Hinckley, in Leicestershire. This Society was settled originally at Bornheim, near Antwerp; they fled to England in 1794, when the French overran the Low Countries. They first found a 
settlement at Carshalton, in Surrey, from whence, in 1810 , they removed to Hinckley. ${ }^{1}$

This convent was founded in the year 1658, by the Baron de Bornheim, according to Mr. Petre, but Philip Howard, a Dominican, (the third son of Henry Frederick, Earl of Arundel) who was afterwards made a Cardinal, had so much concern in the foundation, that he has usually been considered as the founder. He was, at least, the first Prior.

Among the gifts which he bestowed on the convent was this precious volume. This had been the uniform tradition of the House, and it is put beyond doubt, by a memorandum in the book itself, in the hand-writing, as I am informed, of Father Vincent Torry, who was for a long time the Vicar-General of the Dominican Order in England, and a contemporary of Cardinal Howard. It is in these terms : "Conventus Anglo-Bornhemiensis, dono-datus ab $\mathrm{Em}^{\text {mo }}$ Dño Cardinali de Norfolcia fundatore ejusdem Conventus, 1659.-V. T."

It is thus traced, on what we may deem sufficient evidence, to the possession of a member of the house of Arundel in the middle of the seventeenth century.

In a hand-writing of about a century earlier, we find another piece of evidence to the connection of it at that time with an earlier member of the same illustrious house, but one who lived before the dignity had descended upon the Howards. This was Henry Arundel (or Fitz-Alan), Lord Maltravers, then the son and heir-apparent of William, Earl of Arundel, and himself afterwards Earl of Arundel, the last of the earls of the ancient male line of that house. Maltravers, it need hardly be observed, was an old barony, merged into the Earldom of Arundel, and was generally adopted for the designation of the eldest sons of the Earls during their father's life. This Henry, Lord Maltravers, was born about the first year of the reign of King Henry VIII., 1509, and succeeded his father in 1543. He held various offices of trust, and was indeed one of the most conspicuous noblemen of the time. He died in 1579. The book contains a couplet written by him on a blank leaf.

A brief genealogical statement will show the descent from

1 "Notices of the English Colleges and Convents established on the Continent." By the Hon. Edward Petre, 4to, ] 849 , p. 41. 
him of Cardinal Howard, and the probability that a book once his might fall into the Cardinal's hands.

Lord Maltravers and Earl of Arundel, had one son, Henry, called Lord Maltravers, who died without issue in 1556, at the age of nineteen, and two daughters; Jane, Lady Lumley, from whom there are no descendants, and Mary, who married Thomas Howard, the fourth Duke of Norfolk of the Howards. This lady died on August 25, 1557, at Arundel Place, in the parish of St. Clement Danes, and there her only child was born on the 28th of the preceding month of July, a son named Philip. This Philip became Earl of Arundel in right of his maternal descent, the superior title of Duke of Norfolk having been lost by his father's attainder. Philip was the father of Thomas Howard, Earl of Arundel, who is honoured in his line for the patronage which he extended to the arts, and for his great services to his country in having enriched it with so many choice remains of antiquity. He was the father of Henry Frederick, Earl of Arundel, the father of Cardinal Howard : so that the Cardinal was the fifth in descent from Henry, Lord Maltravers, who has inscribed this couplet on a blank page of the book :-

\section{When you yor prayers doe rehers \\ Remembre Henry Mawtrevers.}

These few words, however, open two questions, both requiring to be answered if we propose to give a trustworthy account of the descent of this book from persons who lived in the reign of King Henry VIII. : First, to whom did Lord Maltravers address this couplet? and secondly, how it happened that when the book was in other hands than his, it should still remain in the possession of the Arundel family?

Both these questions may, I think, receive a satisfactory solution.

And now it is necessary to advert to a circumstance to which, hitherto, no allusion has been made, that there are bound up with the beautiful book we have been treating of, ten leaves, forming another book, similar in form to the one before described, but of far inferior execution ; and similar in subject also, being the "Office of the Holy Trinity." This portion of the volume contains its own story; there being 
written in it in the hand of the. Princess Mary, daughter of King Henry VIII. the following words :-

\footnotetext{
Myne owne good Kate as ofte as you can not se me bndyly with your prayers I pray you vysyte me|and wyth thys specially because it is to the hole Trynitie/wherin you shal doo a great pleasure unto me whych am your lovyng mystres and ever wyll be
}

Marye

The ten-leaved book, annexed to the principal book, was therefore the gift of the Princess Mary to some lady of her household, then about to leave her service, and the lady's name was Catherine. We have further assistance towards ascertaining who this lady was, in finding depicted on the second leaf the arms of Arundel; but not Arundel only, but Arundel quartering Maltravers, plainly guiding us to the Lord Maltravers of the time. And when we find that the Lord Maltravers, of whom we have been speaking, married a lady of rank whose name was Catherine, is it too much to presume that this was a farewell gift of the Princess Mary to a lady of her household, in contemplation of her becoming Lady Maltravers? Or that the other portion of the volume was a gift, at the same time, of Lord Maltravers to the same lady, who caused them both to be bound together in the volume as we now have it.

There is something of the sentimental in the couplet inscribed by Lord Maltravers, which certainly favours the notion that if it were presented by him, it was presented under no ordinary circumstances : a signification not only of more than common regard, but of a devotional spirit in the giver, and a recognition of the same spirit in the person to whom it was presented: while this view of the subject explains in the most satisfactory manner how the book remained in the family of Arundel, and descended in the line of that house. Or if it be thought too bold a conjecture, that it was presented as a token of affection to Lady Catherine by Lord Maltravers before their marriage, the less interesting supposition may be formed respecting it, that it had been the property of Lady Catherine before her marriage, and that this couplet had been written in it by Maltravers either before or subsequent to their union. Either supposition serves equally well to show how it is found descending from the time of King Henry VIII. in the line of the Earl of Arundel, since it was from this 
union that the persons who afterwards enjoyed the dignity of Earl of Arundel descended. The question simply is, whether it is more probable that the book was an offering of gallantry or affection to the young lady, who was about to become his bride, or that it was already hers, and she permitted him, before or after marriage, to inscribe the couplet, intended to call him to her remembrance in her more serious hours.

The Lady Catherine, who married Lord Maltravers, was one of the daughters of Thomas Grey, Marquis of Dorset; and though I have not succeeded in finding any list of the household of the Princess Mary sufficiently early, yet it is highly probable that she may have been one of that household, and spoken to by the Princess in the terms of familiarity which we see that she used: for she was no very distant relative of the Princess ; her grandfather, Thomas Grey, Marquis of Dorset, having been half-brother to Queen Elizabeth of York, grandmother of the Princess. Add, that the Greys were a cultivated, a learned, and a devout family, and that Lord Maltravers, then become Earl of Arundel, was a strenuous supporter of the claims of the Princess Mary to the crown, even as against the claims of the Lady Jane Grey, who was niece to Lady Catherine.

On the whole then, the history of the book seems to be this :- that it was prepared by some eminent French or Flemish artist for William, Lord Hastings, the Lord Deputy of Calais about the year 1475 : that it passed, it is not known how, into the possession of either the family of Grey or that of Arundel, and was the property of the Countess of Arundel, who was originally Lady Catherine Grey, one of the household of the Princess Mary; that while in her possession, there was bound up with it a smaller piece, being "The Office of the Holy Trinity," which had been a present to Lady Catherine from the Princess; that they became jointly the property of the grandson of Lady Catherine and the Lord Maltravers Earl of Arundel, Philip Howard, Earl of Arundel, from whom they descended to his great grandson, Philip Howard, who bestowed the book on his convent of Dominicans at Bornheim ; that it remained in the possession of this community when, in 1794, they fled to England; and that it was disposed of by them to its present possessor in 1835 . 
It remains to be added, that while the manuscript was in possession of the Dominicans at Bornheim, and they were still residing at that place, it was brought under the notice of English antiquaries in a communication to the Gentleman's Magazine, anonymous, but by Mr. Webb, who gave a brief description of it. This was soon followed by a communication from the Abbe Mann, of Brussels, containing further details, including fac-similes of the couplet written by Lord Maltravers, and of the votive inscription of the Princess Mary. Both these writers followed a tradition of the Dominicans that the manuscript had been the property of Mary, Queen of Scots, and presented by her to one of her attendants, named Catherine. But this attribution of it was shown to be erroneous, in as subsequent communication to the same Miscellany, by Mr. Brooke, the Somerset Herald at Arms, who perceived, what no one could doubt, that the handwriting of the passage subscribed with the name "Marye" was not that of the Queen of Scots, but of the Princess Mary of England. He also pointed out Lady Catherine Grey as the lady to whom, in all probability, the latter portion of the volume had been presented, and he showed how it would naturally descend from Lord and Lady Maltravers to Philip Howard, the Cardinal of Norfolk. These communications may be found in Gent. Mag. for 1789, pp. 779 and 1078 ; and for 1790, p. 33. 